\title{
George A. Miller (1920-2012)
}

\section{Citation}

Pinker, Steven. 2013. George A. Miller (1920-2012). American Psychologist 68, no. 6: 467-468.

\section{Published Version}

doi:10.1037/a0032874

\section{Permanent link}

http://nrs.harvard.edu/urn-3:HUL.InstRepos:12992311

\section{Terms of Use}

This article was downloaded from Harvard University's DASH repository, and is made available under the terms and conditions applicable to Open Access Policy Articles, as set forth at http:// nrs.harvard.edu/urn-3:HUL.InstRepos:dash.current.terms-of-use\#OAP

\section{Share Your Story}

The Harvard community has made this article openly available.

Please share how this access benefits you. Submit a story.

\section{Accessibility}


"My problem is that I have been persecuted by an integer." So begins one of the best-known papers in the history of psychology, "The magical number seven, plus or minus two: Some limits on our capacity for processing information," published in Psychological Review in 1956. Even if he had done nothing but write that paper, George A. Miller would rank among the most important psychologists of the $20^{\text {th }}$ century. But Miller also fomented the cognitive revolution, invented psycholinguistics and cognitive psychology, imported powerful ideas from the theories of information, communication, grammar, semantics, and artificial intelligence, and left us a sparkling oeuvre which proves that a rigorous scientist needn't write in wooden prose.

Miller was born on February 3, 1920, in Charleston, West Virginia, the only child of Florence and George Miller, a steel company executive; they divorced in 1927, and his mother remarried. Miller studied history and speech at the University of Alabama at Tuscaloosa. To overcome adolescent shyness he joined the drama club, where he fell for a psychology student, Katherine James, and accompanied her to a seminar in the home of Professor Donald Ramsdell, a former student of the Harvard titans E. G. Boring and S. S. Stevens. For Miller, a Christian Scientist who had been brought up to distrust real science, the introduction to intellectual life was exhilarating. "Never before had I heard that kind of conversation-complex arguments over points I would never have thought to question, Ramsdell's rapid deployment of richly suggestive analogies, the easy movement from warmth to heat and back again."

George and Kitty were married in 1939, raised a son and a daughter, and remained married until her death in 1996. After Miller earned his bachelor's degree in 1940 and a master's in 1941, Ramsdell hired him as an instructor and sent him to summer school at Harvard, to which Miller returned as a graduate student in 1943. Working in Stevens's Psych-Acoustic Laboratory, Miller conducted military research on the intelligibility of speech in noise. As he explained to post-Vietnam readers, "My generation saw the war against Hitler as a war of good against evil; any able-bodied young man could stomach the shame of civilian clothes only from an inner conviction that what he was doing instead would contribute even more to ultimate victory. ... The problem was clear: wars are noisy; armies must communicate. By driving ourselves in a race against German and Japanese scientists we shared in an almost religious reflex for national survival." Miller's thesis research on signals for jamming speech, initially classified, earned him a doctorate in 1946 and was published in 1947.

Miller stayed on as an assistant professor, and in 1948 Stevens showed him a paper by Claude Shannon, "A mathematical theory of communication," which introduced the concepts of signals, noise, channel capacity, and information measurement, including the bit. It was a revelation. Miller used it to analyze his data on speech sound identification, and then in his 1951 text Language and Communication (McGraw-Hill), which inaugurated the field of psycholinguistics.

That year he followed J. C. R. Licklider to MIT, where he assembled a confusion matrix for spoken consonants which remains a standard reference today. In another paper from this period, Miller used the analogy of a monkey at a typewriter to explain Zipf's Law, in which the frequency of a word is 
inversely proportional to its rank in frequency. Obscure in psychology, the paper has become a classic in complexity theory, and has been cited in analyses of the statistics of wars, incomes, and Web sites.

It was when Miller applied information theory to cognition that the magical number was immortalized. Miller sought to measure the mind's channel capacity, and noticed that three different tasks gave a similar value. People could reliably associate four to ten labels with continuous stimuli (like loudnesses or line lengths); they could rapidly identify the number of dots on a screen if there were six or fewer; and they could hold between five and nine items in immediate memory. A tempting explanation was that the mind has a single bottleneck which allows seven plus or minus two items to pass through.

Miller resisted the temptation, attributing the commonality to a "pernicious, Pythagorean coincidence," together with "the seven wonders of the world, the seven seas, the seven deadly sins, ..., the seven ages of man, the seven levels of hell, ... and the seven days of the week." But the general principle that attention and memory are limited in capacity remains a cornerstone of cognitive psychology, albeit with the magical number deflated to three or four. It also underlies the widespread advice to limit the items that people must keep in mind (bullets on a slide, digits in a postal code) to fewer than seven.

THE paper's greatest impact came from Miller's observation that immediate memory span was similar whether each item was a binary digit (1 bit), a decimal digit (3.3 bits), a letter of the alphabet (4.7 bits), or a word chosen from a list of a thousand (10 bits). This elasticity suggests that people doesn't passively transmit information but recode it into mind-friendly units, which Miller called "chunks." Recoding, he ventured, is "the very lifeblood of the thought processes." Models of cognition ever since have posited that knowledge is organized into hierarchical networks of chunks within chunks.

The year 1956 was a turning point for another reason: Miller consulted with a wunderkind named Noam Chomsky about models that generated sequences of signals using transition probabilities. Chomsky convinced him that those models could not explain word order in language, which instead required grammatical rules that generate and transform phrase structures. Miller and Chomsky soon collaborated on a set of theorems about grammar and parsing which became the foundations of mathematical linguistics. In the early 1960s Miller and his students ran experiments on sentence memory which, they suggested, demonstrated the psychological reality of Chomsky's theory of grammar at the time. Both the experiments and theory were flawed, but they established the new field of sentence processing, and one finding - that words are easier to recognize in grammatical and sensible sentences-was the first demonstration of top-down processing in language comprehension.

Miller began to see larger implications. At the time psychology was "the science of behavior," and mental entities such as thoughts, plans, and goals were condemned as occult forces and banned. Miller realized that the new ideas he was invoking -information, recoding, hierarchical structurestogether with computer simulations of thinking by Herbert Simon and Allan Newell could make mental stuff scientifically respectable. "I now believe that mind is something more than a four-letter, AngloSaxon word-human minds exist and it is our job as psychologists to study them." Miller wrote a book 
(nominally with Karl Pribram and Eugene Galanter) called Plans and the Structure of Behavior (1960, Holt), which proposed that psychologists should rethink the elementary unit of behavior: not the stimulus-response arc, but a feedback loop. This was a mechanical implementation of a "plan" or "goal" but without any mysterious teleology. More generally, the book was a manifesto for a cognitive revolution in psychology, which Miller also flaunted in the subtitle of his 1962 history Psychology: The Science of Mental Life (Harper \& Row).

Miller had returned to Harvard in 1955, but the Psychology Department, divided into fiefs devoted to Stevens's psychophysics and Skinner's behaviorism, was unwelcoming to his new science. In 1960 Miller and Jerome Bruner founded the Harvard Center for Cognitive Studies, the first institute dedicated to what we now call cognitive science. The Center was an intellectual hothouse, and many of Miller's students and postdocs (including Susan Carey, Jacques Mehler, Donald Norman, Thomas Bever, and Roger Shepard) become major scientists and carried cognitive psychology to other parts of the world.

George Miller could have revolutionized psychology with his ideas alone, but he also was a striking physical presence: tall, handsome, courtly, as urbane in conversation as he was on the page. But his professional life was not always charmed, and he took on responsibilities that consumed him with self-doubt. Two massive projects-a computerized artificial language-learning study, and a lab which videotaped children in conversation - produced only the wistful memoirs "Project Grammarama" (1967) and Spontaneous Apprentices (1977, Seabury Press). He took over the chair of the Harvard psychology department in 1964 and the presidency of the American Psychological Association (APA) in1969, despite a management style he described in this way: "I am constitutionally incapable of demanding that anybody do anything. I may suggest something, even politely request it, or, in dire straits, confess that I am worried about it; when pushed beyond endurance I may unexpectedly explode, confusing everyone." But in his APA presidential address he spawned another deathless meme: an appeal to "give psychology away" by applying it to social problems.

Miller left Harvard for Rockefeller University in 1967, and soon collaborated with Philip JohnsonLaird on Language and Perception (1976, Belnap Press), a heroic exploration of the mental representation of word meanings. In 1979 he moved to Princeton, becoming emeritus in 1990, and began his last project: Wordnet, a high-tech thesaurus which has illuminated the mental lexicon and is incorporated into many systems for search, translation, and language understanding.

When the McDonnell Foundation and Pew Charitable Trusts launched an initiative to midwife a new field of cognitive neuroscience, they tapped Miller to run it, which explains why from 1989 to 1994 their annual meetings took place at golfing resorts, where Miller could indulge his favorite pastime. Miller married Margaret Page in 2008 before passing away from pneumonia on July 22, 2012.

Honors rained down on Miller. The APA gave him the Distinguished Scientific Contribution Award (1963), the American Psychological Foundation Gold Medal (1990), the William James Book Award (1993), and the Outstanding Lifetime Contribution to Psychology Award (2003), and named a prize after him, as did the Cognitive Neuroscience Society. Miller was also honored by the Association 
for Psychological Science and the American Speech and Hearing Association. In 2000 he won the John P. McGovern award from the American Association for the Advancement of Science, and in 1991 the National Medal of Science, the country's highest scientific honor.

Steven Pinker

Harvard University 